\title{
TANTANGAN LIMBAH (SAMPAH) INFEKSIUS COVID-19 RUMAH TANGGA DAN TEMPAT-TEMPAT UMUM
}

\author{
Devi Angeliana Kusumaningtiar ${ }^{1},{\text { Ahmad } \text { Irfandi }^{2} \text {, Veza Azteria }}^{3}$, Erna Veronika ${ }^{5}$, Mayumi \\ Nitami $^{6}$ \\ ${ }^{1,2,3,5,6}$ Prodi Kesehatan Masyarakat, Fakultas Ilmu Kesehatan, Universitas Esa Unggul \\ Jalan Arjuna Utara No. 9 Kebun Jeruk, Jakarta - 11510 \\ deviangeliana@esaunggul.ac.id
}

\begin{abstract}
Based on data from the Ministry of Environment and Forestry, medical waste data for referral hospitals and non-referral hospitals has increased every month. Total medical and non-medical waste generated was 57,253 Kg / day. The amount of medical waste generated is \pm 242 tons / day from around 2,813 hospitals throughout Indonesia with an average medical waste generation of $87 \mathrm{~kg} /$ day / hospital. This illustrates that the amount of unmanaged medical waste is still very large. The purpose of this webinar is to socialize the handling of medical waste and regulations related to medical waste to health workers and the public. The method of implementation uses the method of lecturing (socialization), question and answer, and monitoring and evaluation of participants. The results of this webinar illustrate that there is a need for continuous socialization activities to convey related regulations and understandings to the public regarding the handling of waste and waste contaminated with Covid-19. With this community service activity, this webinar is expected to provide insights and solutions in handling medical waste so that it does not endanger the community and cleaners in handling this waste.
\end{abstract}

Keywords: Medical waste, infectious waste, covid-19, new normal

\begin{abstract}
Abstrak
Berdasarkan data Kementarian lingkungan hidup dan kehutanan data limbah medis rumah sakit rujukan dan rumah sakit tidak rujukan mengalami peningkatan setiap bulannya. Total limbah medis dan non medis yang dihasilkan sebesar $57.253 \mathrm{Kg} /$ hari. Jumlah limbah medis yang dihasilkan sebanyak \pm 242 ton/hari dari sekitar 2.813 rumah sakit di seluruh Indonesia dengan rata-rata timbulan sampah medis sebesar $87 \mathrm{~kg} / \mathrm{hari} /$ rumah sakit.Hal ini menggambarkan jumlah limbah medis yang belum dikelola masih sangat besar. Tujuan webinar ini adalah mensosialisasikan terkait penanganan limbah medis dan regulasi terkait limbah medis pada tenaga kesehatan maupun masyarakat. Metode pelaksanaannya menggunakan metode ceramah (sosialisasi), tanya jawab, dan monitoring serta evaluasi terhadap peserta. Hasil webinar ini memberikan gambaran bahwa perlu adanya kegiatan sosialisasi secara terus menerus untuk menyampaikan regulasi terkait dan pemahaman kepada masyarakat mengenai penanganan limbah maupun sampah yang terkontaminasi covid-19.Dengan kegiatan pengabdian masyarakat webinar ini diharapkan dapat memberikan wawasan dan solusi dalam penanganan limbah (sampah) medis sehingga tidak membahayakan bagi masyarakat maupun petugas kebersihan dalam penanganan sampah ini.
\end{abstract}

Kata kunci : Limbah medis, limbah infeksius, covid-19, new normal

\section{Pendahuluan}

Limbah medis adalah semua limbah yang dihasilkan dari kegiatan medis dalam bentuk padat, cair, dan gas. Limbah medis padat terbagi menjadi sembilan kriteria yaitu limbah padat yang terdiri dari limbah infeksius, limbah patologi, limbah benda tajam, limbah farmasi, limbah sitoksis, limbah kimiawi, limbah radioaktif, limbah kontainer bertekanan, dan limbah dengan kandungan logam berat tinggi. Limbah cair adalah semua buangan air termasuk tinja yang kemungkinan mengandung mikroorganisme, bahan kimia beracun, dan radiaktif yang berbahaya bagi kesehatan. Limbah gas adalah semua limbah yang berbentuk gas yang berasal dari kegiatan pembakaran seperti insinerator, dapur, perlengkapan generator, anestesi, dan pembuatan obat sitotoksik (Kementrian Kesehatan RI, 2010).

Pengelolaan limbah medis berbeda dengan limbah domestik atau limbah rumah tangga. Penempatan limbah medis dilakukan pada wadah yang sesuai dengan karakteristik bahan kimia, radioaktif, dan volumenya. Limbah medis yang telah terkumpul tidak diperbolehkan untuk langsung dibuang ke tempat pembuangan limbah domestik tetapi harus melalui proses pengolahan terlebih dahulu. Untuk limbah medis yang berbentuk gas dilengkapi alat pereduksi emisi gas dan debu pada proses pembuangannya. Selain itu perlu dilakukan pula upaya minimalisasi limbah yaitu dengan mengurangi jumlah limbah yang dihasilkan dengan 
cara mengurangi bahan (reduce), menggunakan kembali (reuse), dan daur ulang (recycle). Penghijauan juga baik dilakukan untuk mengurangi polusi dari limbah yang berbentuk gas dan untuk menyerap debu (Kementrian Kesehatan RI, 2010).

Sampah yang dihasilkan rumah sakit hampir $80 \%$ berupa sampah non medis dan $20 \%$ berupa sampah medis. Sebesar $15 \%$ dari sampah rumah sakit merupakan limbah infeksius dan limbah jaringan tubuh, limbah benda tajam sebesar $1 \%$, limbah kimia dan farmasi 3\% dan limbah genotoksis serta radioaktif sebesar $1 \%$. Negara maju menghasilkan $6 \mathrm{~kg}$ sampah medis per orang per tahun, sedangkan di negara berkembang biasanya menggolongkan sampah menjadi dua golongan yaitu sampah non medis dan sampah medis. Negara berkembang menghasilkan 0,5 sampai 3 (tiga) $\mathrm{kg}$ per orang per tahun(WHO, 2007).

Webinar ini merupakan webinar kesehatan lingkungan berseries yang diadakan setiap bulannya. Pada webinar kali ini membahas mengenai tema "Pengolahan limbah rumah tangga dan tempattempat umum". Pada new normal covid-19 ini masyarakat harus beradaptasi atau membiasakan diri dalam berperilaku hidup bersih dan sehat seperti menggunakan masker saat keluar rumah, cuci tangan, dan lainnya. Semakin meningkatnya kasus covid-19 akan meningkatnya juga limbah medis yang dihasilkan, hal ini mengkhawatirkan bagi masyarakat yang melakukan isolasi mandiri dalam pembuangan sampah yang terkontaminasi covid-19. Harapannya dengan webinar ini dapat sharing dan memberikan manfaat dalam penangganan limbah medis dan isu terbaru terkait limbah medis.

\section{Metode Pelaksanaan}

Kegiatan ini merupakan kegiatan eduksi secara online yang diselenggarakan melalui kegiatan webinar kesehatan lingkungan series yang dihadiri kurang lebih 500an peserta namun jumlah peserta yang mengisi daftar hadir dan bersedia menjadi responden berjumlah 1233 peserta. Pada kegiatan pengabdian masyarakat edukasi online ini dilakukan evaluasi diakhir acara dengan memberikan instrument kuesioner yang telah di respon oleh 1233 peserta. Pelaksanaa webinar dilakukan menggunakan media zoom dan live streaming youtube yang dilaksanakan pada bulan Agustus 2020 dengan tujuan untuk memberikan pengetahuan mengenai penangganan limbah infeksius di skala Rumah Tangga dan tempat-Tempat Umum selama pandemi Covid-19. Sasaran kegiatan ini yaitu seluruh tenaga sanitarian dinkes, puskesmas, RS dan lainnya, praktisi dan mahasiswa di seluruh Indonesia. Alat yang disertakan selama penyuluhan berupa ; poster, background virtual,headset dan materi PPT. berikut poster webinar.

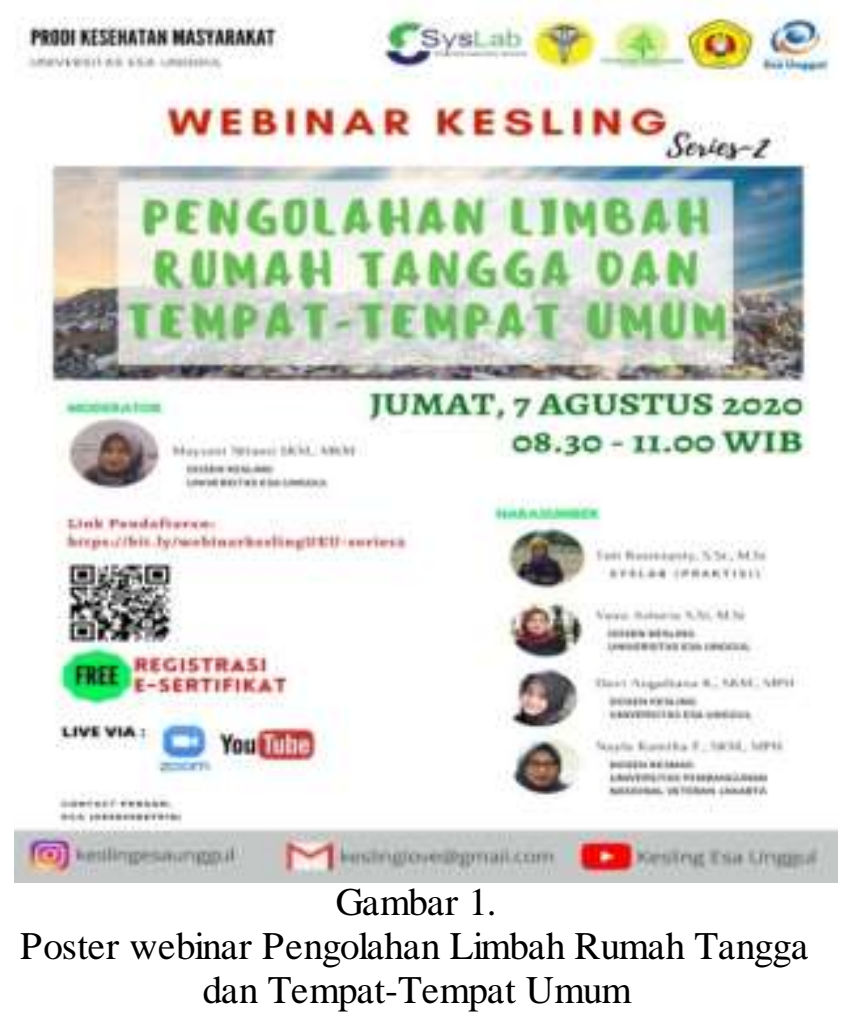

Metode yang digunakan pada pengabdian masyarakat ini adalah :

Sosialisasi

Pada kegiatan sosialisasi dilakukan menggunakan media zoom dengan metode ceramah selama 30 menit. Acara sosialisasi ini dipandu oleh moderator mulai dari pembukaan, penjelasan materi oleh narasumber dan Tanya jawab. Adapun materi yang disampaikan mengenai diet sampah plastik, Tantangan Pengolahan Limbah (Sampah) Infeksius di Tempat-Tempat Umum, Pengolahan Sampah di Pasar dan Pengelolaan Limbah Medis.

\section{Diskusi Tanya jawab}

Kegiatan ini dilakukan kurang lebih selama 30 menit mulai 11.20 - 11.50 WIB, dimana terdapat banyak sekali pertanyaan. Pada tahap ini moderator akan membacakan pertanyaan-pertanyaan dari laman chat atau pertanyaan langsung dari peserta yang kemudian untuk di diskusikan. Monitoring dan evaluasi dengan memberikan form feedback terhadap kegiatan pengabdian kepada masyarakat. Tahap ini dilakukan dengan mengisi link absensi dan beberapa pertanyaan dari materi-materi webinar yang telah disampaikan. Monitoring dan evaluasi ini brtujuan untuk mengetahui mengenai kelangsungan acara webinar dan pemahaman peserta dalam mengikuti acara ini. Adapun rundown kegiatan pegabdian masyarakat :

\section{Tabel 1.}

Rundown Pelaksanaan Pengabdian Masyarakat 


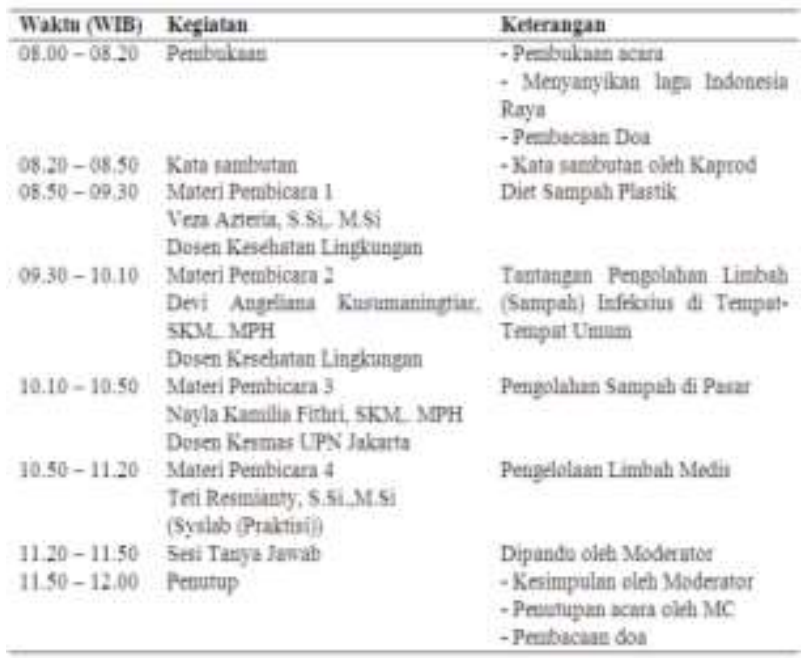

\section{Hasil dan Pembahasan}

Pengabdian masyarakat ini dilakukan secara online melalui kegiatan webinar series yang dilakukan oleh 4 pembicara dan 1 moderator. Kegiatan ini terdiri dari sosialisasi engan metode ceramah di media zoom, diskusi tanya jawab dan monitoring evaluasi. Acara webinar ini di mulai pukul 08-00 - 12.00 WIB yang terdiri dari empat materi pembahasan. Peserta yang mendaftar pada webinar ini \pm 1000an peserta yang tersebar di seluaurh Indonesia, namu yang hadir pada saat webinar \pm 500 an peserta baik dari zoom maupun youtube. Setelah penjelasan dari masing-masing pembicara selesai dilanjutkan ke sesi diskusi tanya jawab kepada peserta. Materi yang sampaikan adalah tantangan limbah (sampah) infeksius rumah tangga dan tempat-tempat umum.

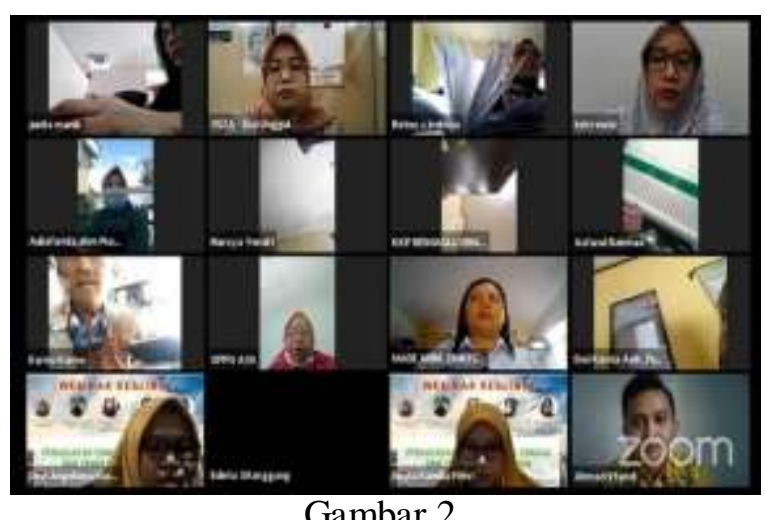

Jumlah Peserta webinar Kesehatan Lingkungan

Pada webinar ini akan dibahas beberapa outline seperti limbah infeksius, isu limbah selama covid-19, dampak limbah infeksius, dan regulasi terkait limbah infeksius. Jika kita ketahui dengan adanya pandemi covid-19 ada beberapa isu penting mengenai limbah infeksius covid-19 seperti jumlah pasien terkonfimasi, kasus suspek dan kontak erat semakin meningkat, penyebaran kasus hamper diseluruh Indonesia, timbulan limbah covid-19 yang bervariasi dan banyak, keterbatasan fasilitas pengolah di daerah, dan pemahamam masyarakat yang masih kurang. Webinar ini berlangsung selama kurang lebih 3 jam dengan metode ceramah dan diskusi tanya jawab.

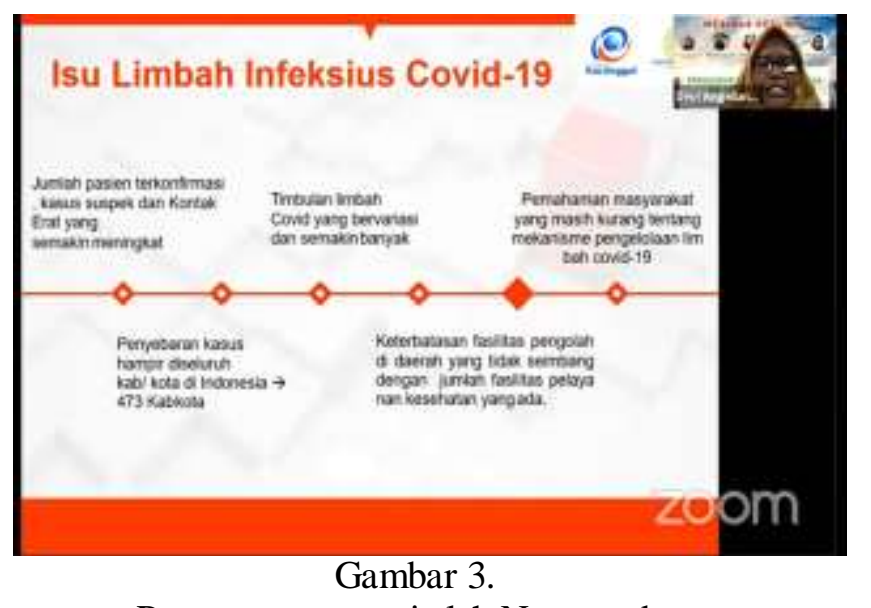

Pemaparan materi oleh Narasumber

Dari beberapa pertanyaan kami rangkum menjadi lima pertanyaan yang dapat mewakili pertanyaan yang lainnya yaitu 1 . bagaimana sikap atau cara dalam menangani sampah medis puskesmas apabila pihak ketiga belum memiliki incinerator ? 2. Bagaimana caranya agar kesadaran masyarakat bias signifikasi terhadap diet sampah (promosi edukasi) dan bagaimana cara simple yang dapat diterima masyarakat desa dalam menangani limbah rumah tangga? 3. Apakah harus dipisah antara sampah masker dan sampah lainnya ? 4. Mengapa sampah medis rumah tangga (masker) harus di masukkan ke dalam plastic sebelum dibuang ke TPS ? 5. Upaya apa yang bias dilakukan oleh masyarakat baik individu, kelompok atau lembaga untuk pengolahan sampah ? kegaiatan diskusi berjalan dengan baik dan lancer dan semua pertanyaan dapat dijawab langsung oleh narasumber.

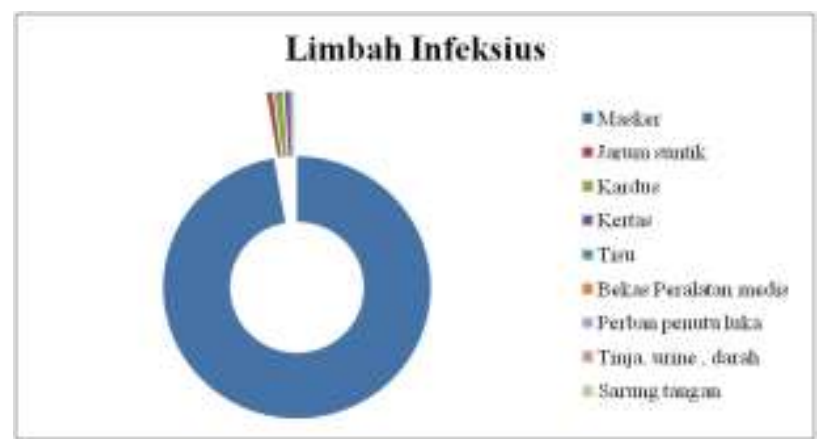

Gambar 4.

Sebaran peserta webinar dalam menjawab pertanyaan mengenai limbah infeksius

Berdasarkan hasil monitoring dan evaluasi yang diberikan kepada peserta menunjukan bahwa sebagian peserta responden dalam menjawab pertanyaan limbah infeksius menajwab masker 
sebesar 1199 (97\%), sedangkan yang lainnya menjawab jarum suntik, kardus, kertas, tisu, bekas peralatan medis, perban, tinja urine darah dan sarung tangan.Pengelolaan limbah padat medis khsusnya limbah infeksius rumah sakit sangat dibutuhkan bagi kenyamanan dan kebersihan rumah sakit, karena dapat memutuskan mata rantai penyebaran penyakit menular, terutama infeksi nosokomial.

Limbah medis infeksius yang berasal dari rumah karantina/isolasi mandiri perlu didisinfeksi terlebih dahulu oleh ODP/PDP/keluarga dengan merendam atau menyemprot limbah dengan cairan mengandung disinfektan yang umum ada dipasaran, seperti bleaching atau pemutih pakaian, karbol, dll.), sebelum dikemas dalam kantong plastik terikat. Hal ini sebagai upaya pencegahan penularan, termasuk terhadap petugas yang bertanggungjawab melakukan pengambilan dan pengangkutan limbah. Untuk mencegah penyalahgunaan masker bekas, penting untukmerusak masker (misalnyadengan menggunting) sebelum dibuang. Menurut (Chandra B, 2007), tempat penampungan limbah dibagi menurut kategorinya, baik plastik pembungkus maupun wadah penampungan limbah. Wadah limbah dan plastik hitam diletakkan di kantor, unit pelayanan, unit gizi dan instalasi lain.

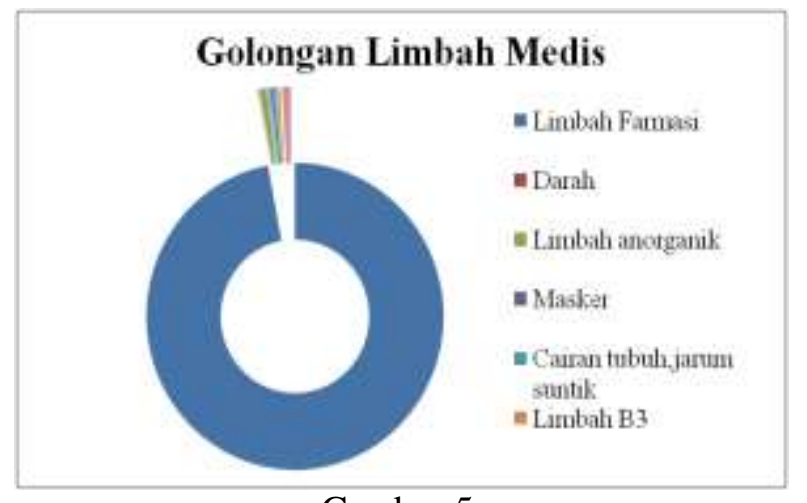

Gambar 5.

Sebaran peserta webinar dalam menjawab pertanyaan mengenai limbah medis

Berdasarkan hasil monitoring dan evaluasi yang diberikan kepada peserta menunjukan bahwa sebagian peserta responden dalam menjawab pertanyaan golongan limbah medis menjawab limbah farmasi sebesar 1197 (97\%).Limbah medis padat merupakan limbah padat yangterdiri dari limbah infeksius, limbah patologi, limbah benda tajam, limbah farmasi, limbah sitotoksis, limbah kimiawi, limbah radioaktif, limbah kontainer bertekanan, dan limbah dengan kandungan logam berat yang tinggi. Limbah medis padat termasuk kategori limbah bahan berbahaya dan beracun. Limbah bahan berbahaya dan beracun adalah sisa suatu usaha dan atau kegiatan yang mengandung bahan berbahaya dan beracun (B3) dimana B3 itu sendiri adalah zat, energy, dan/atau komponen lain yang karenasifat, konsentrasi, danjumlahnya, baik secara langsung maupun tidak langsung, dapat mencemarkan dan merusak lingkungan hidup, dan/ atau membahayakan lingkungan hidup, kesehatan, serta kelangsungan hidup manusia dan makhluk hidup lainnya(Kementeri Lingkungan Hidup Dan Kehutanan, 2015).

Sosialisasi dan pelatihan bagi tenaga kesehatan maupun masyarakat perlu terus dilakukan, salah satunya adalah dengan mengadakan webinar ini. Masih banyaknya masyarakat awam yang belum paham mengenai pengolahan sampah yang terkontaminasi covid-19 di lingkungan rumah tangga maupun di tempat-tempat umum. Pelatihan tenaga kesehatan yang tidak memadai mengakibatkan penanganan dan pembuangan limbah infeksius yang tidak tepat(Kumar et al., 2010). Limbah infeksius ditangani dalam empat langkah: pemilahan, pengumpulan dan pengangkutan, penyimpanan dan pembuangan. Limbah ini harus diolah sebelum pembuangan akhir dengan autoclave atau dengan insinerasi(Kumar et al., 2010). Kebanyakan petugas layanan kesehatan tidak mengikuti pedoman pengelolaan limbah yang tepat dan mengalami luka tajam dan infeksi(Janjua, 2003).Pengelolaan limbah rumah sakit tidak hanya membutuhkan pekerja yang berkomitmen dan terampil, tetapi juga pemantauan ketat(Mostafa et al., 2009). Setiap rumah sakit harus menjaga lingkungan bebas dari infeksi(Maltezou et al., 2012). Oleh karena itu, evaluasi berkala terhadap metode pembuangan di rumah sakit menjadi sangat penting (Mantel et al., 2007).

\section{Kesimpulan}

Limbah medis di masyarakat mengalami peningkatan pada era new normal pandemi Covid19, hal ini terlihat adanya adaptasi baru pada masyarakat dalam memakai masker saat keluar rumah, sarung tangan, cuci tangan dan lainnya. Dibeberapa rumah sakit limbah medis juga mengalami peningkatan seiring dengan bertambahnya pasien yang datang ke rumah sakit. Namun pengolahan limbah medis dari sebelum adanya pandemi Covid-19 masih menjadi kendala. Pemerintah terus melakukan berbagai upaya dalam penangganan limbah medis khususnya limbah infeksius ini. Perumusan kebijakan baru tentang Pengelolaan Limbah Infeksius (limbah B3) da $n$ Sampah Rumah Tangga Dari Penanganan Corona Virus D esease (Covid-19). Sosialisasi kebijakan bagi usaha atau jasa yang menghasilkan limbah maupun bagi masyarakat.

\section{Daftar Pustaka}
Chandra B. (2007). Pengantar Kesehatan Lingkungan. EGC.


Janjua, N. Z. (2003). Injection practices and sharp waste disposal by general practitioners of Murree, Pakistan. JPMA. The Journal of the Pakistan Medical Association, 53(3), 107111.

https://pubmed.ncbi.nlm.nih.gov/12779025/

Kementeri Lingkungan Hidup Dan Kehutanan. (2015). Peraturan Menteri Lingkungan Hidup Dan Kehutanan RI No. 56/MenlhkSetjen/2015 tentang TataCara Dan Persyaratan Teknis Pengelolaan Limbah Bahan Berbahaya Dan Beracun Dari Fasilitas Pelayanan Kesehatan.

Kementrian Kesehatan RI. (2010). Profil Kesehatan Indonesia. 130-133.

Kumar, R., Khan, E. A., Ahmed, J., Khan, Z., Magan, M., Nousheen, \& Mughal, M. I. (2010). Healthcare waste management (HCWM) in Pakistan: current situation and training options. Journal of Ayub Medical College, Abbottabad: JAMC, 22(4), 101105.

https://pubmed.ncbi.nlm.nih.gov/22455273/

Maltezou, H. C., Fusco, F. M., Schilling, S., De Iaco, G., Gottschalk, R., Brodt, H. R., Bannister, B., Brouqui, P., Thomson, G., Puro, V., \& Ippolito, G. (2012). Infection control practices in facilities for highly infectious diseases across Europe. Journal of Hospital Infection, 81(3), 184-191. https://doi.org/10.1016/j.jhin.2012.04.019

Mantel, C., Khamassi, S., Baradei, K., Nasri, H., Mohsni, E., \& Duclos, P. (2007). Improved injection safety after targeted interventions in the Syrian Arab Republic. Tropical Medicine and International Health, 12(3), 422-430. https://doi.org/10.1111/j.13653156.2006.01802.x

Mostafa, G. M. A., Shazly, M. M., \& Sherief, W. I. (2009). Development of a waste management protocol based on assessment of knowledge and practice of healthcare personnel in surgical departments. Waste Management, 29(1), 430-439. https://doi.org/10.1016/j.wasman.2007.12.0 09

WHO. (2007). Wastes From health-Care Activites. 